\title{
Studying the Relationship between Workplace Incivility and Employees' Job Positive Attitude in Rafsanjan
} Tejarat Banks

\author{
Mohammad Ziaddini ${ }^{1}$ (Ph.D) \\ Hamid Mohammadi ${ }^{2}$
}

Doi:10.5296/ijhrs.v3i4.4770

URL: http://dx.doi.org/10.5296/ijhrs.v3i4.4770

\begin{abstract}
Workplace Incivility is one of negative and deviational behaviors involved in present organizations and can affect on employees' attitudes. This research aims to study the relationship between Workplace Incivility and employees' job positive attitude in Rafsanjan Tejarat banks. Statistical society of the research includes employed employees of Rafsanjan Tejarat banks containing 152 people and regarding limitation of statistical society, statistical sample is selected equal to statistical society. Measuring instruments are two questionnaires. Questionnaire of discourtesy behavior that was designed and organized by Hasani (2013) is 0.92. Also to measure job positive attitudes, standard questionnaire of Saeedi (2012) is used for which validity is 0.98 . Using Cronbach alpha method reliabilities for every questionnaire are 0.87 and 0.94 respectively. To test hypotheses Kendal and Spearman correlation coefficients are used. All statistical analyses are done by SPSS statistical software. Regarding the results it is determined that there is no meaningful relationship between Workplace Incivility and its components ( excluding others, gossiping, roughness and hostility) with employees' job positive attitudes in Rafsanjan Tejarat banks.
\end{abstract}

Keywords: Discourtesy behavior in Workplace, Attitude, Job Positive Attitudes

\section{Introduction}

Organizational misbehavior includes reaction and performances occurred in workplace that is such breaking behavioral laws in work (Ahmadi \& Dehnavi, 2:2012). Workplace Incivility has much negative effect on employees' job, work behaviors and job attitudes. Also paying attention to Workplace Incivility is important because it increases these behaviors. Discourtesy may lead to more roughness and changes to property of organizational atmosphere. Impolite reactions increase disharmony (Anderson \& Pearson, 214:1999) and impose much individual, group and organizational costs (Pearson \& Purus, 71:2009). Generally discourtesy creates forceful conditions for all people who work in group (Peni \& Espector, 2005).Attitudes are seriously effective on planning and forming behaviors, creating

\footnotetext{
${ }^{1}$ Mohammad Ziyaaddini department of management. Rafsanjan branch. Islamic azad university. Rafsanjan. Iran

${ }^{2}$ Corresponding author: Hamid Mohammadi. Department of management. Rafsanjan branch. Islamic azad university. Rafsanjan. Iran. Mail: m16339@yahoo.com
} 
motives, satisfying needs and orienting tendencies (Azarbayejani et al, 136:2004).Having a positive insight and attitude at work and job (preferably innovative works and job) is inspired by religious and valuable tenets in several cultural, social, economic, scientific and technological areas. Positive look is such a glance by which someone looks at work lovely and interestingly and considers it as a factor of individual and social success and respects work as worship religiously. Philosophically this question may not be answered exactly whether a man likes work or hates it in his nature; but it is certainly explained that human big products are indebted to work and effort. Traditional and incorrect conception of societies that consider greedy to work and effort more than making a living is an important factor to support negative look at work. This idea that considers forbidden work and making wealth resulted in...., genius, creation and effort, should be correct and changes to a positive attitude. However one important factor of economic non progression is resulted in people's lack of positive look at work (Hosseini, 17:2013).

\section{Problem explanation}

Recognizing employees' attitude is so important to perceive one's behavior in organization and anticipating its behavior. Managers pay attention to employees' attitude because it affects one's behavior (Goldner, Persian translation, 48:2005). Management respects employees' manners increasingly. Employees' manners relate to behaviors that are sensitive for organization. Generally employees have constant and recognizable manners to their workplace including payments, workplace conditions, and job duties descriptions and... (Moorhead, Griffin, Persian translation; 78:2007). A person can have thousand attitudes, but a limited number of job attitudes are paid attention in organizational behavior (Seyyed Javadin, 90:2005).

Attitude includes a combination of beliefs and anxieties that makes a person ready to look at others and several things and groups positively or negatively. Attitudes are a summary of evaluating things that finally undertake to anticipate or guide future acts or behaviors (Ganji, 19:2009).Positive attitude is the missing link of success in life and job problems. By a positive attitude human have a light look at a good and proper life and also following their goals they undertake their acts (Tahmasbi, 44:2012). In contrary, by a negative attitude people ever complain about everything. People having a positive attitude are ever in better and more appropriate condition from viewpoint of health and job success. Researches show that human feelings are effective on his health seriously. People having a positive attitude are less involved depression and several diseases from catching a cold to cancer than people having a negative attitude and they improve fast. Basically several firms and institutes tend to employ optimist people because they try more to be successful and get higher degrees in their jobs (Tahmasbi, 45:2012). Unfortunately some people encounter more difficulties in the way of their development because of positive attitude to their life and as a result of decreasing life quality and level and even some come back because of their negative attitude and manner (Rahmani, 18:2013). People having a positive attitude walk faster and take long steps, instead people having negative attitude hump and walk slow and take short steps. Looking at a man who walks by a raised head and high shoulders you can understand that he is so high self-confident and in contrast someone who has bent shoulders and walk slowly has negative 
attitude (Tahmasbi, 45:2012). Employees' negative beliefs and attitudes should be improved; because they can change to a long negative culture that even influences new employees (Azmoodeh, 57:2013). Organizations seen with many negative attitudes are known by these factors: increasing complaints, noting realize tasks and losing the hope of future improvement. In these conditions organizations involve to find a solution. Regard that negativism is a contagious matter which influences even the most positive employees (Azmoodeh, 57:2013).Negative attitude leads to be indifference to live and lack of concern about daily affairs. Also sadness, suicide thoughts, noting focus of thoughts, hopelessness, depression, physical problems, withdrawing from others, lack of desire to meet others and even children are other signs of this disease (Danaifard \& Panahi, 6:2009).

Employees having negative attitude are considered as threats for organization because they can guide other employees to negative thoughts. However attitudes can change using different methods. It is necessary for managers to try for promoting employees' job positive attitudes by skip of preventing factors and support of progressing factors. According to studies, success or defeat of an organization are based on employees' positive attitudes rather than other factors. Positive attitudes of organization's people lead to individual and organizational success (Sharafaddin, 1:2009).

It is worth to note that attitudes should be satisfying like responses related to behavior motives and lead to responses that create happiness in people directly. However, although it isn't exactly determined the relationship between some attitudes with requirements systems of a person, group, society and organization, but a relationship can be found with the mediator among them. Authorities pay increasingly attention to study the attitude in order to perceive social behavior. In this regard it is hypothesized that attitudes determine behaviors and this hypothesis implicitly explains that changing people attitudes can anticipate their behaviors rather than control them (Khajeh Sarvari et al, 122:2009). Certainly it should be regarded that to change behaviors their attitudes should be changed. Recent researches show that changing attitude increasingly sometimes causes to change behavior decreasingly (Arbodonat, 7:2009).

In other side discourtesy behavior in workplace should be regarded as an obstacle for job positive attitudes (Bartlet, 2009). Low deviational behaviors that point to lower forms of inter-individual misbehavior, lead to exist an extent of researches called discourtesy (impoliteness) in workplace (Lim et al, 2008). Discourtesy is followed by some negative consequences such as low satisfaction, high stress, weak performance, low organizational commitment, increasing turnover and inefficiency. Discourtesy behavior can be intentional or unintentional and includes an extended spectrum of behaviors from noting smile to hurt others' feelings intentionally (Bartlet,2009). The results of researches show that changing employees' attitudes is so useful to promote individual and organizational success in order to decrease employees' misbehaviors and discourtesy (Ahmadi, 15:2008). Workplace Incivility has many negative effects on employees' health, work behaviors and job attitudes (Anderson \& Pearson, 214:1999). Lim et al, (2008) explain that impolite behaviors create inequal position of power. This means that while emerging discourtesy in organization as a habit, its consequences should be anticipated; such consequences that influence people's attitudes in organization. However it forms employees' behaviors. In one hand discourtesy is one 
common factor in organizations (Garry, 2005). Workplace Incivility is as a negative emotional event and influences job attitudes. Regarding above, the main question of research includes: Is there a relationship between Workplace Incivility and employees' job positive attitude in Rafsanjan Tejarat banks? Answering this question needs a scientific research.

\section{Theoretical principles of research variables Workplace Incivility}

Work deviational behavior includes a voluntary behavior which violates organizational manners and threatens both organization and employees' health. According to above definition work deviation is voluntary, because employees don't have any motivation to match with manner expectations and/or they are motivated to violate these expectations. In definition organizational manners are such manners explained by organizational policies, rules and procedures and are presented as work standards. Here manners mean dominant office union of organizations not manners of a work group or micro-cultures (Salmani \& Radmandf, 6:2009).

Discourtesy is a kind of misbehavior that leads to breaking and rupturing communications and agreement (Pearson et al, 125:2001). While discourtesy is defined as a purposeful behavior against a person which causes to create a stressful space and bigger problems, policy of good behavior simply explains that people should communicate by a good behavior (Wikipedia, 2013). In job field impolite behavior occurs as mutual respect manners are violated in workplace (Pearson et al, 125:2001). Discourtesy is in the bottom of misbehavior appendix in workplace and this definition doesn't include roughness, injury or even clear conflict, although it may lead to create them (Johnson \& Indvik, 2001). In management and organizational literatures Anderson and Pearson (1999) present the most acceptable and common definition of discourtesy. They define Workplace Incivility as:"Weak deviational behaviors and indefinite intention in order to hurt a person. These behaviors violate the current manners about mutual respect in workplace. Discourtesy behaviors are clearly impolite and rudely behaviors which are emerged by ignoring others (Anderson \& Pearson, 457:1999). Three main properties of discourtesy include violating manners, indefinite intention and its weakness (Rezai et al, 41:2012). Discourtesy refers to abnormal behaviors that occur by an indefinite intention and doing shallow behaviors to hurt others (Anderson \& Pearson, 457:1999).

\section{Problems resulting from emerging discourtesy behavior in workplace}

Organizational behavior may be destructive and threaten well-being of a social system. For example it can be followed by economic and social costs such as insurance losses and credit reduction. Determined samples of work deviation include: robbery, commission of an offence, breaking laws, and ant production behavior, destructive behavior, receiving graft and wasting resources, impolite behavior to co workers and refraining from efforts (Salmani \& Radmand, 53:2009). Statistically, 3.4 of workers steal their employers at least one time and even some personnel do it many times. However just 30 or 50 percent of work deviations are reproached (Ahmadi \& Dehnavi, 2:2012). 
In one the primary studies about prevailing deviational behaviors, Harper reports that 33 to 75 percent of studied employees explained that they committed one behaviors of vandalism, sabotage openly and secretly, absenteeism uncoordinatedly and robbery. More recent researches also explain that economic, technology and social changes lead to increasingly levels of deviational behaviors in workplace. According to U.S Department Of Justice (2000) 1.7 million Americans fall a victim of several forms of deviational behaviors annually. Unfortunately there aren't exact statistics and numbers in the field of deviational activities (related to people or related to organization) in Iran. However looking at virtually, it doesn't seem that these statistics and numbers are low in Iran. Particularly by the statistics and numbers related to the cost of deviational behaviors for organizations this fact should be regarded that deviational behaviors influence effectiveness in organizations unaccountably (Dunlop \& Lee, 2004). In a research Boyes \& Jones (1997) show that 29\% personnel of a store explained themselves sick while they were healthy. This behavior is explained as avoiding behaviors because it allows personnel to avoid their work and workplace emotionally and physically and interestingly people who commit absenteeism are delayed more than others (Jones, 2001. Quoted by Ahmadi \& Dehnavi, 6:2012). However along with open and secret effects of deviational behaviors on organizations and their employees, many researches and theorists pay attention to the results of these behaviors. This attention leads to present many multi level models out of Iran in which deviational behaviors are regarded as the result variable in the last level (Ahmadi \& Dehnavi, 11:2012) but lead to costs and damages for organizations. Current estimates about the cost of these behaviors are more than several billion dollars for American organizations (Lawrence \& Robinson, 2007). These cases of misbehavior often lead to some costs and damages for organization; for example Bensimon research estimates 4.2 billion dollars damages one year (Wikipedia,2013).

Bennett \& Robinson (2000) explain that 75 percent of personnel commit to robbery at least one time. Small and commonplace crimes are important challenges of present jobs and include some cases such as stealing reservoir list, personnel robbery, vendors fraud, stealing goods, job mistakes and.... For example personnel stealing includes 47 percent of commonplace robberies and leads to 15.8 billion dollars damage for the U.S (Ahmadi \& Dehnavi, 7-6:2012).

Impolite behavior is followed by some consequences such as low satisfaction in work- signs of mental pressures like stress and anxiety; increasing these behaviors increases its physical and mental results and consequences (Ahmadi \& Dehnavi, 7:2012). In England presented evidences by Ryner \& Cooper show that many workers fall a victim to their colleagues and other employees' misbehaviors in workplace during previous six months (Dunlop \& Lee, 2004).

Results of findings show that 14 thousands of American workers are killed by job events annually and more than 2 million are injured too. Among reported job events in the world 250 million lead to injury and 300 thousand lead to death annually. Numbers of job events in developing countries are 3 or 4 times more than developed industrial countries (Khodayari \& Oveisi, 2:2012). 


\section{Parameters of measuring discourtesy in workplace}

Discourtesy is defined as low level deviational behaviors (Anderson \& Pearson, 1999). Discourtesy includes some behaviors such as:

1-Excluding people: people make an effort to leave others in different degrees (Bartlet, 13:2009).

2-Gossipping: A spectrum of ill-speaking behaviors from giving false and negative information about colleagues to breaking orders and spreading negative, true and false information about a person or a group (Bartlet, 13:2009)

3-Hostility: A kind of Workplace Incivility resulted from non-physical hurt (Saduk et al, 435:2007).

4-Roughness: Violating others' personal limits with no reason (Saduk et al, 435:2007).

Generally discourtesy affects on job turnover intention and staying in organization by creating stressful conditions for all people who work in work group. Workplace Incivility is as a negative emotional event and affects on work attitudes such as job turnover and organizational justice. Organizational justice is a variable which is influenced by discourtesy in workplace. Experimental evidences show that different kinds of misbehaviors relate to injustice perception. Orton et al (2010) believe that discourtesy as a kind of misbehavior leads employees to feel that they aren't behaved fairly (Rezaee et al, 42:2012).

\section{Attitude and Belief}

Attitude and belief are two words or in better definition two variables which have not only general meanings among society people, but also because of especial definitions regarded in psychological methodology they are the most common keywords in papers and researches related to psychology that relates to behavioral studies; and this kind of studies are the most common descriptive researches that include several branches of science containing psychology, medicine, health development, management, information and communications technology, electronic commerce, banking, marketing, sports and... and every researcher who wants to examine the effective factors on deciding about emerging a behavior, uses this kind of studies (Jalalian, 2011).

Attitude is resulted from the Latin word of Optus that means suitability and adaptation and other root of this word is Aptitude that means mental state and readiness for act. However they differentiate two groups of attitudes in using both roots in social psychology: mental attitudes and motion attitudes (Heidari, 2012). Spenser was one of people who first used the word of attitude. In one of his work in 1852 he writes: "true judgment about discussed questions is somehow related to attitudes while disputing organization and to haw a true attitude it is necessary to recognize the average of human beliefs' correctness or incorrectness (Javeri, 79:2010).

Forooqi defines attitudes as" attitude is in the field of social psychology and presents evaluating attitude which influences people's social behavior, processing and interactions and is somehow constant; and recognizing people's attitudes can anticipate and control their behaviors and it is such an evaluation or estimate that occurs properly or improperly. In other side can be regarded as a method of readiness towards agreeing or disagreeing something or is an opinion that is explained about people, things and events and reflects human kind of 
feeling. Sometimes attitude is a mental tendency in human that interacts against agreeing or disagreeing one thing or position related to it (Saeedi, 34:2013). But generally it can be concluded that attitude is in an internal state and act isn't behavior but a precondition of behavior (Foroqi, 4:2010).

In other definition attitude includes readiness to interact specially against a person, thing, thought or position and is less constant during time. Although some attitudes are constant during time, but some changes while concentrating information and experiences (Ansarii \& others, 79:2007).

Attitude includes a positive or negative feeling to a person or thing. As you say that you don't love a person, so you explain your attitude. Attitude influences behavior but it doesn't necessarily anticipate it. Some attitudes are pointed based on their effects on human behavior. Social scientists from several scientific courses agree this point that attitude can be regarded as an intendancy and readiness to response to things, people or definitions properly or improperly. Consequences of attitude but not itself can be observed. Attitude is an important anticipating factor for act and some people who have negative attitude threatens organization, because they can guide other employees to negative thoughts; attitudes can change by making satisfied. Someone who wants to satisfy others should be a confident and neutral person, has an attractive appearance and emotional behavior. A low self respect person is satisfied soon, because he trusts himself less (Jaberi, 86:2010).

Attitude or manner includes being ready for reaction against one person, thing, thought or position (Rezaian, 202:2006).

Attitude is a set of beliefs, emotions and behavioral intentions to one thing, person or event. In other words it is a relatively constant desire to one person, thing or event emerged in feeling and behavior (Qulipour, 108:2008).

Attitude includes a negative and positive emotional state to a subject (Reza,2011).

Attitude is an evaluation or estimation that occurs about a person, thing or event properly or improperly. Attitude is reflection of one's feeling to one thing or person. As you say that "I like my job", you explain your attitude about job (Rabinz, Persian translation, 40:2006).

In other words its elements are regarded: "combination of knowledge, feelings and being ready for an action to a certain thing is one's attitude to a social matter" (Reza, 2011).

Attitude is a mental or nervous state explaining desire that is organized by experience and affects on one's responses to all related subjects and positions directly or dynamically (Autoclain, Persian translation, 538:2008).

Attitude shows cognitive and emotional effect instead of personal experience of perceived thing or social subject and a desire to answer to that thing. In this meaning attitude is a "potential mechanism" which guides behavior (Karimi, 162:2009). Attitude is an idea explained about a people, things and behaviors and reflecting one's feeling about it (Rabinz, Persian translation, 280:2006).

According to mentioned definitions, attitudes have a strong effect on planning and forming behaviors, creating motivations, meeting needs and directing attitudes. So studying them is a big part of social psychology (Azarbayejani et al, 137:2004). No single meaning can get a main position in social psychology such as the meaning of "attitude" (Mark \& Neon, Persian translation, 119:2004). 


\section{Job Positive Attitudes Models}

As Sung (20040 explains and regarding above explanations 1-work effort, 2-one of effective indirect factors on productivity that is feelings or attitudes and 3-above behavior forms helping role of basic principles of employees' job positive attitudes. So to measure productivity Sung got a behavior-attitude model based on employees 'positive attitudes. He defines the words of employees' job positive attitudes as voluntary job positive attitudes to achieve organization's goal that is based on Rach (1994), Leman \& Simpson (1992) definitions and to measure employees' job positive attitudes, he uses following parameters that are based on Kamplila \& Lanquist (2003), Van Dean \& Leapin (1998) models:

-Desire to help others in order to achieve on purpose

-Effort to get a quality higher than needed level

-Innovation to solve work problems

-Desire to get new responsibilities and achieving determined deadlines and sometimes completing mission before determined deadline (Ansari et al, 53:2010).

In other model, Salami in his research presents job positive attitudes in three dimensions:

Job satisfaction, job commitment and turnover intention

Managers found that employees' job positive attitudes have important effects on individual and organizational performance and success. He believes that paying attention to employees' job positive attitudes and modifier role of leadership on employees and directing organization employees by more experienced employees cause to decrease motivations of organization turnover and increase employees' job satisfaction and finally increase job satisfaction. Job satisfaction as the most important attitude explains human perception and his public orientation to his job and organization. A man by high job satisfaction likes his job and has a positive attitude to it (Forooghi, 8:2010).

As, positive feelings and attitudes about a job show job satisfaction and cause to more commitment and connection and less absenteeism and replacement; so it is so important to perceive attitudes.

Recognizing employees' attitudes and directions is a caution for potential problems. Managers should be aware about employees who try to decrease cognitive anisotropy and manage them. Job satisfaction is variable which allocates most studies of organizational behavior either in theoretical or scientific researches from job planning to supervision to itself. Many clear and implicit definitions are presented about job satisfaction. Such a definition that may have the most effect on this area relates to Lock's (1976) definition about job satisfaction (Forooghi, 22:2010

\section{Research Theoretical Framework}

In this research job positive attitude is the first variable (benchmark variable) that is studied, such a variable that is tried to explain and interpret its changes by Workplace Incivility (anticipator variable).

Discourtesy includes some behaviors such as excluding people, gossiping, hostility and aggression (Saduk et al, 435:2007).

Work positive attitudes include the components of: desire to help or guide others, trying to get quality more than needed level, employees' skills and employees' creativity, accepting 
responsibility and achieving determined deadlines.

Discourtesy behavior in workplace is emphasized as an obstacle for existing work positive attitudes. Discourtesy is followed by some negative consequences such as low satisfaction, high stress, weak performance, low organizational commitment, increasing turnover and inefficiency. It is worth to note that to change behavior their attitudes should be changed. Recent researches show that high rate of changing attitude sometimes changes behavior in a low rate (Arbodonat, 2009). Rabinz believes that there is a relationship between attitudes and behavior that is one's attitude determines the works he performs (Rabinz, 1998).

\section{Research hypotheses \\ Main research}

There is a relationship between Workplace Incivility and employees' job positive attitudes in Rafsanjan Tejarat Banks.

\section{Secondary hypotheses}

1- There is a relationship between excluding people and employees' job positive attitudes in Rafsanjan Tejarat Banks.

2- There is a relationship between gossiping and employees' job positive attitudes in Rafsanjan Tejarat Banks.

3- There is a relationship between hostility and employees' job positive attitudes in Rafsanjan Tejarat Banks.

4- There is a relationship between aggression and employees' job positive attitudes in Rafsanjan Tejarat Banks.

\section{Research methodology}

This research belongs to application researches from nature and method point of view and to descriptive researches of correlation kind for which data is gathered by field methods. Research statistical society includes all employed employees in Rafsanjan Tejarat Banks including 152 people. Statistical method is used to determine sample size because of limiting statistical society.

\section{Data gathering instruments}

In this research data gathering instruments include two questionnaires;

a)Questionnaire of discourtesy in workplace: this questionnaire contains 21 questions that measures Workplace Incivility by four components of excluding others, gossiping, hostility and aggression and is designed as five-option form (very low, low, average, much very much) for which validity and reliability are 0.92 and 0.87 respectively.

b) Questionnaire of job positive attitudes: second questionnaire is designed to measure job positive attitudes containing 18 questions that evaluates job positive attitudes by six components of : desire to help or guide others, trying to get quality more than needed level, employees' skills and employees' creativity, accepting responsibility and achieving determined deadlines that is designed as five-option form (very low, low, average, much very much) for which validity and reliability are 0.98 and 0.87 respectively.

\section{Data analysis method}


To describe gathered data this research used different kinds of statistical parameters such as abundance, several tables and curves. To determine correlation Kendal and Spearman correlation tests are used. All statistical analyses were performed by SPSS computer software.

\section{Results of research hypotheses}

Main hypothesis: There is a relationship between Workplace Incivility and employees' job positive attitudes in Rafsanjan Tejarat Banks.

Data analysis shows that Kendal and Spearman test correlation coefficients between two variables of Workplace Incivility and employees' job positive attitudes in Rafsanjan Tejarat Banks are -0.059 and -0.083 and p-value (meaningfulness) equal to 0.294 and 0.307 respectively and higher than meaningfulness level of $\alpha=0.05$, so in this level $\mathrm{H} 0$ assumption that is existence of relationship isn't rejected and as a result there is no meaningful relationship between Workplace Incivility and employees' job positive attitudes in Rafsanjan Tejarat Banks.

\begin{tabular}{|c|c|c|c|c|c|c|c|c|c|}
\hline \multicolumn{9}{|c|}{ Discourtesy in workplace } & Variable \\
\hline \multirow{2}{*}{$\begin{array}{l}\text { determinant } \\
\text { Coefficient }\end{array}$} & \multirow{2}{*}{$\begin{array}{l}\text { Kind of } \\
\text { relation } \\
\text { Ship }\end{array}$} & \multirow{2}{*}{$\begin{array}{l}\text { Meaningful } \\
\text { Relation }\end{array}$} & \multicolumn{3}{|l|}{ Spearman } & \multicolumn{3}{|l|}{ Kendal } & Test \\
\hline & & & Numbers & $\begin{array}{l}\text { Meaning } \\
\text { fulness }\end{array}$ & $\begin{array}{l}\text { Correlation } \\
\text { Coefficients }\end{array}$ & Numbers & $\begin{array}{l}\text { Meaning } \\
\text { fulness }\end{array}$ & $\begin{array}{l}\text { Correlation } \\
\text { Coefficients }\end{array}$ & \multirow[t]{2}{*}{$\begin{array}{l}\text { Job } \\
\text { positive } \\
\text { attitudes }\end{array}$} \\
\hline $0 / 004$ & - & No & 152 & $0 / 307$ & $-0 / 083$ & 152 & $0 / 294$ & $-0 / 059$ & \\
\hline
\end{tabular}

First secondary hypothesis: There is a relationship between excluding people and employees' job positive attitudes in Rafsanjan Tejarat Banks.

Data analysis shows that Kendal and Spearman test correlation coefficients between two variables of excluding people and employees' job positive attitudes in Rafsanjan Tejarat Banks are -0.055 and -0.083 and p-value (meaningfulness) equal to 0.338 and 0.311 respectively and higher than meaningfulness level of $\alpha=0.05$, so in this level $\mathrm{H} 0$ assumption that is existence of relationship isn't rejected and as a result there is no meaningful relationship between excluding people and employees' job positive attitudes in Rafsanjan Tejarat Banks.

\begin{tabular}{|c|c|c|c|c|c|c|c|c|c|}
\hline \multicolumn{9}{|l|}{ Excluding } & Variable \\
\hline \multirow{2}{*}{$\begin{array}{l}\text { determinant } \\
\text { Coefficient }\end{array}$} & \multirow{2}{*}{$\begin{array}{l}\text { Kind of } \\
\text { relation } \\
\text { Ship }\end{array}$} & \multirow{2}{*}{$\begin{array}{l}\text { Meaningful } \\
\text { Relation }\end{array}$} & \multicolumn{3}{|l|}{ Spearman } & \multicolumn{3}{|l|}{ Kendal } & Test \\
\hline & & & Numbers & $\begin{array}{l}\text { Meaning } \\
\text { fulness }\end{array}$ & $\begin{array}{l}\text { Correlation } \\
\text { Coefficients }\end{array}$ & Numbers & $\begin{array}{l}\text { Meaning } \\
\text { fulness }\end{array}$ & $\begin{array}{l}\text { Correlation } \\
\text { Coefficients }\end{array}$ & \multirow[t]{2}{*}{$\begin{array}{l}\text { Job } \\
\text { positive } \\
\text { attitudes }\end{array}$} \\
\hline $0 / 003$ & - & No & 152 & $0 / 311$ & $-0 / 083$ & 152 & $0 / 338$ & $-0 / 055$ & \\
\hline
\end{tabular}


Second secondary hypothesis: There is a relationship between gossiping and employees' job positive attitudes in Rafsanjan Tejarat Banks.

Data analysis shows that Kendal and Spearman test correlation coefficients between two variables of gossiping and employees' job positive attitudes in Rafsanjan Tejarat Banks are -0.075 and -0.109 and p-value (meaningfulness) equal to 0.200 and 0.181 respectively and higher than meaningfulness level of $\alpha=0.05$, so in this level $\mathrm{HO}$ assumption that is existence of relationship isn't rejected and as a result there is no meaningful relationship between gossiping and employees' job positive attitudes in Rafsanjan Tejarat Banks.

\begin{tabular}{|c|c|c|c|c|c|c|c|c|c|}
\hline \multicolumn{9}{|l|}{ Gossiping } & Variable \\
\hline \multirow[t]{2}{*}{$\begin{array}{l}\text { determinant } \\
\text { Coefficient }\end{array}$} & \multirow{2}{*}{$\begin{array}{l}\text { Kind of } \\
\text { relation } \\
\text { Ship }\end{array}$} & \multirow[t]{2}{*}{$\begin{array}{l}\text { Meaningful } \\
\text { Relation }\end{array}$} & \multicolumn{3}{|l|}{ Spearman } & \multicolumn{3}{|l|}{ Kendal } & Test \\
\hline & & & Numbers & $\begin{array}{l}\text { Meaning } \\
\text { fulness }\end{array}$ & $\begin{array}{l}\text { Correlation } \\
\text { Coefficients }\end{array}$ & Numbers & $\begin{array}{l}\text { Meaning } \\
\text { fulness }\end{array}$ & $\begin{array}{l}\text { Correlation } \\
\text { Coefficients }\end{array}$ & \multirow[t]{2}{*}{$\begin{array}{l}\text { Job } \\
\text { positive } \\
\text { attitudes }\end{array}$} \\
\hline $0 / 007$ & - & No & 152 & $0 / 181$ & $-0 / 109$ & 152 & $0 / 200$ & $-0 / 075$ & \\
\hline
\end{tabular}

Third secondary hypothesis: There is a relationship between hostility and employees' job positive attitudes in Rafsanjan Tejarat Banks.

Data analysis shows that Kendal and Spearman test correlation coefficients between two variables of hostility and employees' job positive attitudes in Rafsanjan Tejarat Banks are -0.038 and -0.060 and p-value (meaningfulness) equal to 0.509 and 0.460 respectively and higher than meaningfulness level of $\alpha=0.05$, so in this level $\mathrm{H} 0$ assumption that is existence of relationship isn't rejected and as a result there is no meaningful relationship between hostility and employees' job positive attitudes in Rafsanjan Tejarat Banks. 


\begin{tabular}{|c|c|c|c|c|c|c|c|c|c|}
\hline \multicolumn{9}{|l|}{ Hostility } & Variable \\
\hline \multirow{2}{*}{$\begin{array}{l}\text { determinant } \\
\text { Coefficient }\end{array}$} & \multirow{2}{*}{$\begin{array}{l}\text { Kind of } \\
\text { relation } \\
\text { Ship }\end{array}$} & \multirow{2}{*}{$\begin{array}{l}\text { Meaningful } \\
\text { Relation }\end{array}$} & \multicolumn{3}{|l|}{ Spearman } & \multicolumn{3}{|l|}{ Kendal } & Test \\
\hline & & & Numbers & $\begin{array}{l}\text { Meaning } \\
\text { fulness }\end{array}$ & $\begin{array}{l}\text { Correlation } \\
\text { Coefficients }\end{array}$ & Numbers & $\begin{array}{l}\text { Meaning } \\
\text { fulness }\end{array}$ & $\begin{array}{l}\text { Correlation } \\
\text { Coefficients }\end{array}$ & \multirow[t]{2}{*}{$\begin{array}{l}\text { Job } \\
\text { positive } \\
\text { attitudes }\end{array}$} \\
\hline $0 / 0005$ & - & No & 152 & $0 / 460$ & $-0 / 060$ & 152 & $0 / 509$ & $-0 / 038$ & \\
\hline
\end{tabular}

Fourth secondary hypothesis: There is a relationship between aggression and employees' job positive attitudes in Rafsanjan Tejarat Banks.

Data analysis shows that Kendal and Spearman test correlation coefficients between two variables of aggression and employees' job positive attitudes in Rafsanjan Tejarat Banks are -0.068 and -0.103 and p-value (meaningfulness) equal to 0.236 and 0.207 respectively and higher than meaningfulness level of $\alpha=0.05$, so in this level $\mathrm{HO}$ assumption that is existence of relationship isn't rejected and as a result there is no meaningful relationship between aggression and employees' job positive attitudes in Rafsanjan Tejarat Banks.

\begin{tabular}{|c|c|c|c|c|c|c|c|c|c|}
\hline \multicolumn{9}{|l|}{ Aggression } & Variable \\
\hline \multirow{2}{*}{$\begin{array}{l}\text { determinant } \\
\text { Coefficient }\end{array}$} & \multirow{2}{*}{$\begin{array}{l}\text { Kind of } \\
\text { relation } \\
\text { Ship }\end{array}$} & \multirow{2}{*}{$\begin{array}{l}\text { Meaningful } \\
\text { Relation }\end{array}$} & \multicolumn{3}{|l|}{ Spearman } & \multicolumn{3}{|l|}{ Kendal } & Test \\
\hline & & & Numbers & $\begin{array}{l}\text { Meaning } \\
\text { fulness }\end{array}$ & $\begin{array}{l}\text { Correlation } \\
\text { Coefficients }\end{array}$ & Numbers & $\begin{array}{l}\text { Meaning } \\
\text { fulness }\end{array}$ & $\begin{array}{l}\text { Correlation } \\
\text { Coefficients }\end{array}$ & \multirow[t]{2}{*}{$\begin{array}{l}\text { Job } \\
\text { positive } \\
\text { attitudes }\end{array}$} \\
\hline $0 / 005$ & _- & No & 152 & $0 / 207$ & $-0 / 103$ & 152 & $0 / 236$ & $-0 / 068^{-}$ & \\
\hline
\end{tabular}

\section{Discussion and Conclusion}

Negative behaviors in workplace include an extended spectrum of behaviors in which one side is discourtesy behaviors and other side is aggressive behaviors. Workplace Incivility is presented as a low and useless performance for organization while it leads to harmful behaviors for organization and employees less. Workplace Incivility is defined as an abnormal low level behavior (Anderson \& Pearson, 1999).

Job positive attitudes is desire of employees to do work efforts in order to increase productivity and improving performance related to employees' job positive attitudes. Job positive attitude is a factor that affects on one's work efforts and feelings directly (Ansari \& others, 2010). . Discourtesy is followed by some negative consequences such as low 
satisfaction, high stress, weak performance, low organizational commitment, increasing turnover and inefficiency. Vikers (2006) explain that occurring Workplace Incivility shouldn't be regarded as an unimportant problem. An unimportant behavior can change to a big problem (Blaw et al 2005). Discourtesy behavior can be intentional or unintentional and includes an extended spectrum of behaviors from noting smile to hurt others' feelings (Bartlette, 2009). Using some maneuvers to decrease discourtesy among employees is so important. The results of researches show that changing employees' attitudes to promote individual and organizational success and decrease employees' misbehavior and discourtesy is important (Ahmadi, 2003).

There is no relationship between Workplace Incivility (excluding people, gossiping, aggression and hostility) and employees' job positive attitudes in Rafsanjan Tejarat Banks. Rabinz believes although in past it was concepted that attitude relates to behavior highly, that is one's attitude determines works he performs, but in recent years this relationship called A-B explains that there is a little or no relationship between them. Because social pressures force people to behave in contrast to their attitudes (Rabinz, Persian translation; 325:2006), of course it should be regarded that attitude should change to change behavior. Recent researches show that high rate of changing attitude sometimes leads to change their behaviors by low rate (Arbodnat, 2009). Lover and Ion in their study as network structure and feeling in mutual relationships explain while human make communications mutually in network of social relationships get positive feeling. If communication among human involves confusion, positive attitude will be exhausted gradually. They present some ideas in the field of communications based on communication correlation theory. From the view point of symbol mutual act, human as an actor must make communication (Aqahosseini \& Safavi zadeh, 5:2010). As some variables as mediator variables (such as perceived organizational justice, social pressures and...) can be the complementary of relationship between Workplace Incivility and job positive attitudes, it can be explained if employees don't perceive injustice and social pressures after the event of discourtesy, discourtesy leads to their positive job attitude less.

\section{Research suggestions}

To decrease and omit self-reporting error it is suggested that questionnaires are performed during time.

\section{Suggestions for other researchers}

1-Regarding that above research studied variables of discourtesy behaviors in workplace and employees' job positive attitudes in Rafsanjan Tejarat Bans, so it is suggested that other students and researchers perform this study in executive systems and industrial places if they are desired.

2-It is suggested that future researches pay more attention to affecting individual factors related to Workplace Incivility and job positive attitudes.

3- It is suggested to study some variables such as social justice and doing as society does as mediator variable related to Workplace Incivility and job positive attitudes. 


\section{References}

1-Ahmadi,A; Dehnavi,F;2012."Organizational deviations: forms, challenges and introducing kinds of misbehaviors". Internet paper in site: www.ahmadiblogfa.ir 2-Ahmadi,M. 2008, "Organization and management(general management) principles,cultural researches press, eighth print, Tehran

3-Autoklain, B, 2008; "Social psychology:. Translated by Ali Mohammad Kardan, Andisheh press, eighth print, second volume, Tehran

4-Azarbayejani, M; 2004, "Social psychology by looking at Islamic resources, Samt press, Tehran

5-Azmoodeh,Z, 2011; “Changimg employees' negative attitude (Managements and its branches".Internet paper in site:

http://modir-e-movafagh.blogsky.com/2011/05/17/post-76

6-Agha Hosseini,T; Safavizadeh, N. 2010; "Classroom management methods and skills of relationships with students". Internet paper in site http://socialgroup .blogfa.com/post-8.aspx, in 2013.

7-Agha Hosseini, Kh \& Safavi zadeh M, 2010, "Positive Attitude". Schools magazine, No.1. sixth term. pp 55-68

8-Ansari ,A and Ostadi, H, Javeri, F; 2007 "Studying the relationship between organizational health and employees positive attitudes in Isfahan tax offices, Tax magazine, No.6, Serial 44, p 51

9-Javeri, F, 2010; "Studying the relationship between organizational health and employees positive attitudes in Isfahan tax offices, M.A thesis, Dehagan open university, pp 79-85

10-Jalalian, M, 2011. "What is difference between belief and attitude?" Internet paper in site: http://www.drmehrdad.com

11-Hasani,S; "Studying the relationship between Workplace Incivility with perceived organizational justice and employees' organizational commitment in Rafsanjan executive systems". M.A thesis of Rafsanjan open university.

12-Hosseini,H; "Requirements of realizing national production, work support and Iranian capital", economic news services of Islamic Republic newspaper, Ordibehesht $23^{\text {rd }}$

13-Heidari,H; "What's attitude?", Internet paper in site: http://heb88.blogfa.com/post-33aspx

14-Khadayari,M, Oveisi, S; "Mediating role of excluding perception in workplace in relationship between exchanging leader-member with deviationalbehaviors and psychological well-being"; Social psychology researches, first term, No.3, pp 92-103

15-Khajeh Sarvari, Gholamreza, Asadi, Alireza; "Role of the clergy and religious intellectuals in changing general attitude of Iranian to Hossein movement in flow of Islamiic Republic", Scientific-research magazine of Islamic Republic studies, 2009 winter, fourth year, No.15, p 12

16-Danaifard, H; Panahi, B; 2009; “Analyzing employees' job attitudes of public organizations, explaining organizational silence atmosphere and organizational silence behavior". Management research, No.7, Tehran 
17-Rabinz, A; "Organizational behavior principles", translated by Ali Parsia \& Mohammad Eerabi, publicated by cultural research office, Tehran

18-Rahmani, M. 2013, "Positive attitude", Internet paper in site http://shahtoot127.blogfa.com/post-15.aspx

19-Reza.Kh. 2001, “What'sattitude?” Internet paper in site:

http://neshaneh2010.persianblog.ir/post/21

20-Rezaian, A; 2006, "Organizational behavior management". Samt press, fifth print, Tehran.

21-Rezaee, F; Noori,A; Arizi,H. 2012. "Incivility in workplace and lapse of duty intention regarding mediation role of organizational justice". Knowledge and research magazine in operational psychology, $12^{\text {th }}$ year. No.4, winter, Isfahan, Khgorasgan open university

22- Salmani, D,; Radmand, M. 2010. "Studying the role of organization and management in emerging work deviational behaviors". Public management issue, first period, No.3; fall and winter, pp 51-68, Tehran

23-Saeedi,M; 2013. "Studying the relationship between employees' job silence and their job positive attitudes in Kerman custom, M.A thesis, Rafsanjan open university

24-Seyyed javadin. R, 2005, “Managing organizationalbehavior”. , Negahe danesh press.Second press, Tehran

25-Sharafaddin Hossein, 2009; “Attitude". Maarefat magazine, politic science and sociology, summer, seventh year, No. 25

26-Tahmasbi, Z. 2012, "Positive attitude"; Internet paper in site:

www.ghasresokhan.blogfa.com2

27-Forooghi.A, 2010; "A research about organizational developed behavior", Tehran. Pp 3-5

28-Qolipour, A. 2008. "Organizational behavior management". Third print, Samt press, Tehran

29-Karimi,Y. 2010. "Attitude and changing attitude". Tehran, Virayesh press

30-Goldner, A. 2005; "Western sociology crisis", translated by Farideh Momtaz. Enteshar co. second print. Tehran

31-Ganji, M and Ganji, H. 2009; "Atkinson \& Hiliard psychology field". Termeh press, first print, Shabak 66-1-978-946-7609

32-Mark Roush Blaw and Edil Neon, 2006. "Social psychology, " translated by Seyyed Mohammad Dadgaran, Morvarid, Tehran. Second print, p 119

33-Mark \& Neon, 2006, "Social psychology, “ translated by Seyyed Mohammad Dadgaran, Morvarid, Tehran. Second print, p 119

34-Moorhead, J. Griffin, R. 2007; “Organizationalbehavior”. Translated by Seyyed Mahdi Alvani and Gholamreza Meemarzadeh, Mortvarid press, second print, Tehran 35-Honner, J; Vanek, M; 2006, "Attitudes and changing them". Translated by Ali Mehdad, Jungle press, First print, Tehran 